\title{
Primary pancreatic lymphoma: A diagnostic conundrum
}

\author{
Amara Okoli, Nischala Ammannagari, Kathleen Laveaux, \\ Kiran Nakkala
}

\section{To the Editor,}

Primary pancreatic lymphoma (PPL) is an extremely rare non-epithelial tumor constituting far less than $1 \%$ of all pancreatic neoplasm $[1,2]$. Clinical and imaging findings are otherwise non-specific in differentiation of pancreatic lymphoma from other pancreatic cancers. Herein, we report a case of PPL presenting as multiple masses in the pancreatic head, body and tail.

An 86-year-old female presented to the emergency department for evaluation of a three-week history of progressive fatigue and night sweats without anorexia, abdominal pain or weight loss. She had a medical history of diet-controlled type II diabetes mellitus and denied use of alcoholic beverages or tobacco products.

On admission, physical examination revealed a mildly pale woman without palpable adenopathy. She had a mildly distended abdomen, without tenderness, organomegaly or fluid thrill. Laboratory examination showed normal platelets and white blood cell count, hemoglobin $10.2 \mathrm{~g} / \mathrm{dL}\left(11.5^{-15.5} \mathrm{~g} / \mathrm{dL}\right)$, hematocrit $30.7 \%$ (34-36\%), predominantly direct hyperbilirubinemia $2.7 \mathrm{mg} / \mathrm{dL}(0.1-1.0 \mathrm{mg} / \mathrm{dL})$, lactate dehydrogenase of $327 \mathrm{U} / \mathrm{L}$ (100-190 U/L), alkaline phosphatase $313 \mathrm{U} / \mathrm{L}$ (38-135 U/L), normal amylase, lipase of $638 \mathrm{U} / \mathrm{L}$ (50$290 \mathrm{U} / \mathrm{L}$ ), and marginal elevation in transaminases: AST $71 \mathrm{U} / \mathrm{L}(14-36 \mathrm{U} / \mathrm{L})$, ALT $53 \mathrm{U} / \mathrm{L}(9-52 \mathrm{U} / \mathrm{L})$. She had

Amara Okoli ${ }^{1}$, Nischala Ammannagari ${ }^{1}$, Kathleen Laveaux ${ }^{2}$, Kiran Nakkala ${ }^{3}$

Affiliations: ${ }^{1}$ Resident, Internal medicine, Bassett Medical Center, Cooperstown, New York, United States; ${ }^{2}$ Attending physician, Hematology \& Oncology. Bassett Medical Center, Cooperstown, New York, United States; ${ }^{3}$ Attending physician, Digestive \& Liver disease Bassett Medical Center, Cooperstown, New York, United States, Kiran.

Corresponding Author: Amara Okoli, MD, MPH, Bassett Medical Center, One Atwell Road, Cooperstown, New York 13326, United States; Ph: + 1410865 9980; Fax: +1 607 547 6612; E-mail: amara.okoli@bassett.org.

Received: 20 May 2013

Accepted: 12 August 2013

Published: 17 May 2014 normal complement levels, negative hepatitis panel, nonspecific antinuclear antibody elevation, and an elevated CA 19-9 level at $102 \mathrm{U} / \mathrm{mL}(<55 \mathrm{U} / \mathrm{mL})$. Abdominal ultrasound reported intra-hepatic and common biliary ductal dilatation, cholelithiasis with a small amount of ascites, and a questionable mass in the pancreatic tail. Magnetic resonance cholangiopancreatography reported multiple cystic lesions in the uncinate process, pancreatic body, and tail associated with a non-dilated pancreatic duct.

Computed tomography (CT) scan of the abdomen and pelvis were not suggestive of widespread adenopathy but revealed extensive infiltrative appearance in the retroperitoneum suspicious for lymphoma associated with pleural effusions and ascites. Evaluation with endoscopic ultrasound revealed two heterogeneous hypoechoic cystic mass lesions in the pancreas: a 3.2x2.2 $\mathrm{cm}$ lesion in the distal body and a $3.5 \times 3.2 \mathrm{~cm}$ multicystic lesion in the pancreatic head each of which were biopsied (Figure 1). Additional findings included common biliary ductal dilatation, multiple hypoechoic cystic lesions in the

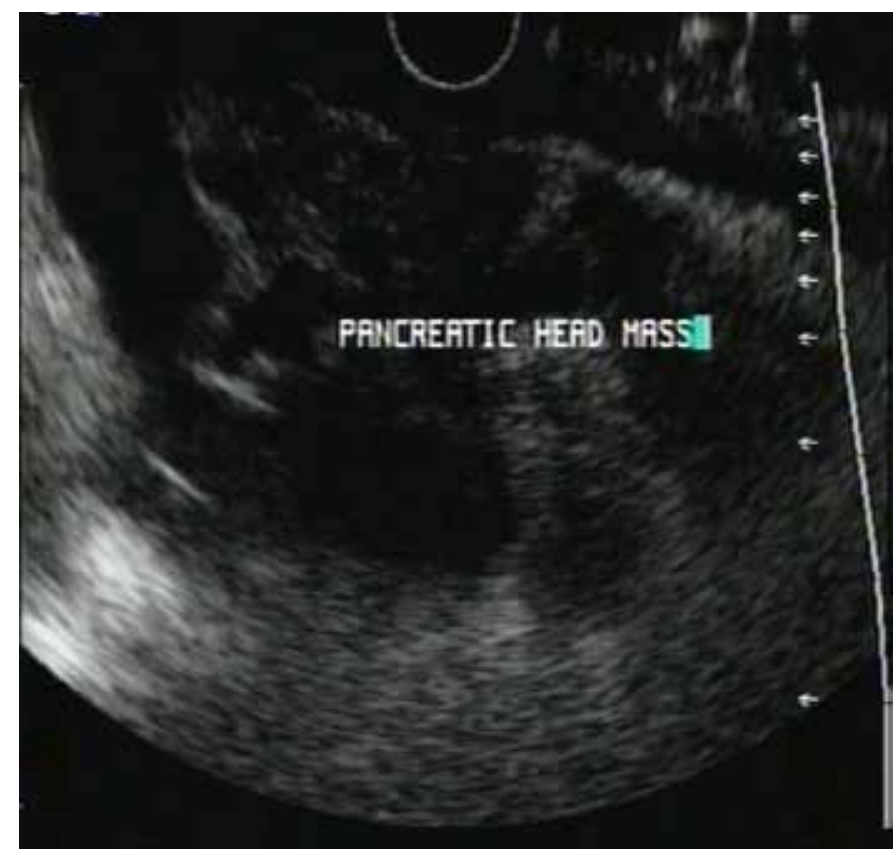

Figure 1: Hypoechoic pancreatic head mass on EUS in patient with primary pancreatic lymphoma 
pancreatic body and tail, and duodenal obstruction from the pancreatic head mass. Histopathological analysis of the specimen revealed a CD20 positive diffuse large B-cell lymphoma (Figure 2). Immunohistochemistry was additionally positive for the following tumor markers: CD45, CD10, B-cell lymphoma (BCL) 6, and BCL-2; and negative for cytokeratin AE1/AE3 cocktail, chromogranin, synaptophysin, CD56, cyclin D1, CD23, CD3 and CD5. Ki67 was reported as equivocal.

Though no surgical intervention was performed, she successfully had percutaneous biliary drainage with stent placement and started systemic chemotherapy with rituximab, cyclophosphamide, vincristine, and prednisone (R-CVP) within days o agnosis. She was dose reduced for the first cycle due to obstructive jaundice with peak total hyperbilirubinemia of $5.8 \mathrm{mg} / \mathrm{dL}$ (0.1-1.0 mg/ dL) which subsequently resolved. CT imaging after three cycles of systemic chemotherapy showed interval decrease in biliary ductal dilatation, near complete resolution of bilateral pleural effusions and ascites, and decrease in size of pancreatic lesions. She has completed six cycles of therapy per NCCN guidelines with a partial response expected at the least based on clinical, laboratory, and imaging parameters.

Most reported cases of PPL reference a median age of presentation of 55-60 years with a male preponderance. Clinical presentation and imaging studies are often very similar to that of pancreatic adenocarcinoma [2, 3]. Primary pancreatic lymphoma often presents as an isolated pancreatic mass mimicking adenocarcinoma, but without marked pancreatic ductal dilatation on imaging (Table 1). Unlike other pancreatic cancers, obstructive jaundice, as was seen in our patient, is an uncommon presenting feature of pancreatic lymphoma [3]. Histopathological analysis by fine-needle aspiration (FNA) is required for the diagnosis of this rare variety of non-Hodgkin's lymphoma [4, 5]. Surgery is often

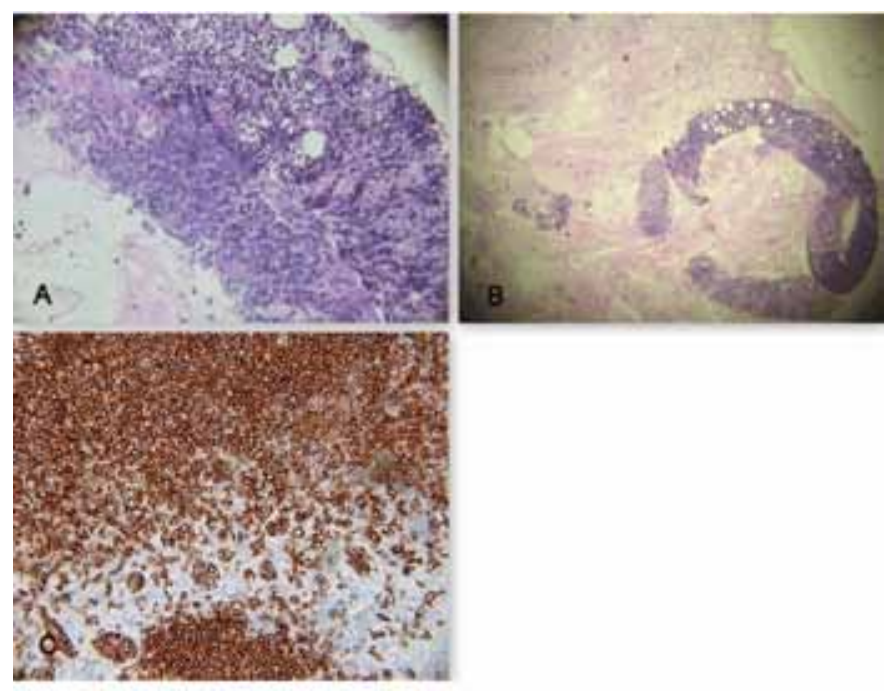

Figure 2: Photomicrograph slides of pancreatic tissue in primary pancreatic lymphoma,(A, B): H\&E stain of FNA sample of pancreatic tissue under high and low power view, (C) CD 20 positive B-cells.
Table 1: Differences between primary pancreatic lymphoma and pancreatic adenocarcinoma

\begin{tabular}{|c|c|c|}
\hline & $\begin{array}{l}\text { Primary Pancreatic } \\
\text { Lymphoma }\end{array}$ & $\begin{array}{l}\text { Primary } \\
\text { Pancreatic } \\
\text { Adenocarcinoma }\end{array}$ \\
\hline Origin & $\begin{array}{l}\text { Non epithelial tumor } \\
\text { arising from lymphatic } \\
\text { tissues }\end{array}$ & $\begin{array}{l}\text { Arises from } \\
\text { epithelial cell }\end{array}$ \\
\hline $\begin{array}{l}\text { Clinical } \\
\text { presentation }\end{array}$ & $\begin{array}{l}\text { Obstructive jaundice is } \\
\text { an uncommon feature }\end{array}$ & $\begin{array}{l}\text { Obstructive } \\
\text { jaundice is a } \\
\text { common feature }\end{array}$ \\
\hline Diagnosis & $\begin{array}{l}\text { Bulky localized tumor } \\
\text { mass without marked } \\
\text { pancreatic ductal } \\
\text { dilatation on imaging is } \\
\text { suggestive }\end{array}$ & $\begin{array}{l}\text { Typically presents } \\
\text { with marked } \\
\text { pancreatic ductal } \\
\text { dilatation on } \\
\text { imaging }\end{array}$ \\
\hline Treatment & $\begin{array}{l}\text { Potentially curable with } \\
\text { chemotherapy primarily. } \\
\text { Role of surgery and } \\
\text { radiotherapy are } \\
\text { controversial }\end{array}$ & $\begin{array}{l}\text { Treatment } \\
\text { primarily by } \\
\text { surgical resection. } \\
\text { Radiotherapy and } \\
\text { chemotherapy may } \\
\text { play adjuvant roles }\end{array}$ \\
\hline Prognosis & Very good & Poor \\
\hline
\end{tabular}

reserved for the rare instance when percutaneous or endoscopic biopsies are not diagnostic, or to bypass biliary obstruction [1]. Lactate dehydrogenase (LDH) and beta-2 microglobulin levels might be helpful tools in its differentiation from other common pancreatic cancers. While pancreatic adenocarcinoma is often associated with a grave prognosis, PPL is potentially treatable $[1,2]$. The cyclophosphamide, doxorubicin, vincristine and prednisone (CHOP) based regimen is the most commonly used therapy. Addition of rituximab, given $\mathrm{CD} 20$ positivity to this regimen has been reported to increase complete response rate and prolong both overall and event free survival in recent years [1]. Doxorubicin was not used in the index case to prevent risk of therapy related cardiotoxicity given the patient's age at presentation. This report highlights the need for a heightened clinician awareness of PPL. Though clinically difficult to differentiate from pancreatic adenocarcinoma, its potential curability with therapy makes accurate diagnosis worthwhile. The role of surgery and radiotherapy in treatment remains controversial [1, $4,5]$.

\section{How to cite this article}

Okoli A, Ammannagari N, Laveaux K, Nakkala K. Primary pancreatic lymphoma: A diagnostic conundrum. Int $\mathrm{J}$ Hepatobiliary Pancreat Dis 2014;4:7-9. 
Article ID: 100014IJHPDAO2014

$* * * * * * * * *$

doi:10.5348/ijhpd-2014-14-LE-2

\section{Acknowledgements}

Maurice Bouchard

\section{Author Contributions \\ Amara Okoli - Acquisition of data, Analysis and interpretation of data, Drafting the article, Critical revision of the article, Final approval of the version to be published \\ Nischala Ammannagari - Acquisition of data, Analysis and interpretation of data, Drafting the article, Critical revision of the article, Final approval of the version to be published \\ Kathleen Laveaux - Analysis and interpretation of data, Critical revision of the article, Final approval of the version to be published \\ Kiran Nakkala - Analysis and interpretation of data, Critical revision of the article, Final approval of the version to be published}

\section{Guarantor}

The corresponding author is the guarantor of submission.

\section{Conflict of Interest}

Authors declare no conflict of interest.

\section{Copyright}

(C) 2014 Amara Okoli et al. This article is distributed under the terms of Creative Commons Attribution License which permits unrestricted use, distribution and reproduction in any medium provided the original author(s) and original publisher are properly credited. Please see the copyright policy on the journal website for more information.

\section{REFERENCES}

1. Saif MW. Primary pancreatic lymphomas. JOP 2006 May 9;7(3):262-73.

2. Piesman M, Forcione DG. A case of pancreatic lymphoma. MedGenMed 2007 Aug 9;9(3):32.

3. Lin $\mathrm{H}, \mathrm{Li} \mathrm{SD}, \mathrm{Hu} \mathrm{XG}, \mathrm{Li}$ ZS. Primary pancreatic lymphoma: Report of six cases. World J Gastroenterol 2006 Aug 21;12(31):5064-7.

4. Ribeiro A, Vazquez-Sequeiros E, Wiersema LM, Wang KK, Clain JE, Wiersema MJ. EUS-guided fineneedle aspiration combined with flow cytometry and immunocytochemistry in the diagnosis of lymphoma. Gastrointest Endosc 2001 Apr;53(4):485-91.

5. Du X, Zhao Y, Zhang T, et al. Primary pancreatic lymphoma: A clinical quandary of diagnosis and treatment. Pancreas $2011 \mathrm{Jan} ; 40(1): 30-6$.
Access full text article on other devices

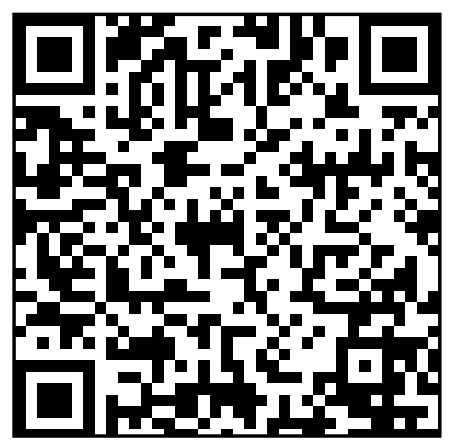

Access PDF of article on other devices

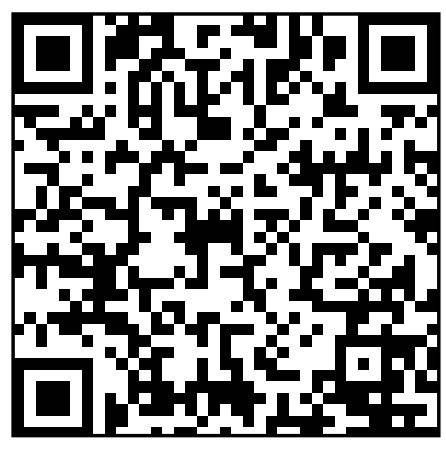

